\title{
Lake Drawdown: The Value Of 2 Inches Of Water
}

\author{
Russell Kashian, (Email: kashianr@uww.edu), University of Wisconsin Whitewater
}

\begin{abstract}
This study uses the hedonic price model to estimate the effect a change in water level has on the value of real estate on Lake Koshkonong in Wisconsin. Hedonic techniques are employed to show that a 2 inch reduction in the lake's water level had a significant effect on Lake Koshkonong's shoreline property values. The body of existing research demonstrates that changes in both the subjective and objective indicators of value are important for estimating the implicit value of water quality in hedonic analyses. This paper provides new evidence on the economic harm created by the reduction of water levels and the concurrent publicity created by the action.
\end{abstract}

\section{INTRODUCTION}

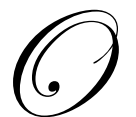

$\mathrm{n}$ the border of Wisconsin and Illinois, at the locus of the Milwaukee, Madison and Chicago metropolitan areas, is a large shallow lake. About 30 miles to the southeast of Madison, 60 Miles to the southwest of Milwaukee, and 110 miles to the northwest of metropolitan Chicago, Lake Koshkonong is subject to a government order requiring it to draw down its water level below its historic levels. After years of debate, through the adjustment of the lake's wicket gates, a drawdown was enforced in 2003. This paper examines the economic impact of this drawdown and the corresponding adverse publicity.

A 1991 order by the Wisconsin Department of Natural Resources (DNR) resulted in lower Lake Koshkonong water levels. In light of the relatively shallow nature (7 feet at its deepest point) and large size (over 10,000 acres) of the lake, this order had adverse effects on the homeowners surrounding the lake. The DNR-ordered lake level results in lower lake levels than those observed over the past 18 years for approximately $50 \%$ of the summer season (in those years, this exceeded the 776.3 elevation). The resulting water level reductions are as much as approximately 0.5 feet. This DNR order produces slightly higher water levels than those that have been observed under lowest flow conditions, which occur approximately $10 \%$ of the season. For the remaining $40 \%$ of the summer season, the DNR 1991 orders produce water levels very similar to those that have occurred over the past 18 years.

The difference between the 1987 through 2005 water levels on Lake Koshkonong and the level resulting from the 1991 DNR order is primarily due to the fact that the Indianford dam had not been fully operable. Therefore, maintaining the 1991 DNR order in force continued the significantly lower water levels producing a number of impacts on the use of the shoreline and both public and private access to the water. The impacts include: (a) Potential loss of functionality of piers and ability to use the piers for boating, swimming and other water activities for all or portions of the period between May and October; (b) Loss or diminishment of the ability to access the shoreline with watercraft; (c) Degradation of the appearance of the shoreline and exposure of "mud flats" under low water level conditions; (d) Reduction of the areas of navigability by larger motorized craft; (e) Exposure of rocks and other obstacles that can damage watercraft.

This paper tests the hypothesis that the drawdown caused a diminution in property value along the lake relative to what would be expected in the absence of drawdown. This paper recognizes that, while the water reduction is measurable, the concurrent adverse publicity is not. As a result, it is these inseparable issues that may have had an adverse impact. 


\section{LITERATURE REVIEW: THE VALUE OF A LAKE LOT TO THE HOMEOWNER}

Hedonic prices are the implicit prices of attributes rather than the observed prices of differentiated products. Econometrically, implicit prices are estimated by a reduced form multivariate regression model. In terms of housing, hedonic values are the result of a model of equilibrium housing price differentials. This model hypothesizes that homeowners maximize their net utility by trading changes in price for changes in housing attributes.

A given housing unit is best characterized as a bundle of attributes which describe the structure itself, the land upon which it is built, and the relevant locational characteristics. Claims of valuation comparisons which ignore the differences between these units ignore the unique bundle of attributes. Thus, proximity to water, water depth, and length of shoreline are three of the housing bundle's locational attribute. At any given time, there exists a given distribution over space of the supplies of these attributes, since the housing stock alters only slowly over time and the attributes are perfectly inelastic in supply (Brown and Pollakowski, 1977).

When forming policy, hedonic analysis provides decision makers the ability to explore the implicit prices of environmental goods. While the physical environment helps guide supply issues, obtaining the demand curve requires knowledge of the prices that consumers are willing to pay. With marketed goods, such prices are observable. However, since environmental goods are nonmarketed, researchers must use other techniques to obtain the prices. One example of a nonmarketed good would be a foot of shoreline on a lake. Since it is almost impossible to purchase a single foot of shoreline (not associated with lot acreage), hedonic analysis extracts the contribution of the environmental good to the price of the marketed good.

While economists generally assume that people know their preferences with certainty and those choices are based on observable, well-understood measures of the goods and services (and their component characteristics), this may not be the case considering complex, heterogeneous commodities where some component characteristics are not observed. For instance, in the case of housing markets, characteristics such as the number of bedrooms are easily observed and quantified. On the other hand, some characteristics (such as the property's environmental quality) may not be readily observable. These characteristics may be inferred by the purchaser. It is the inference of lake level that holds economic consequence.

Economic psychologists recognize that objective data may not represent valid measures when used as proxies for analyzing consumer decision making behavior (Singh 1988). Puto (1987) suggests that consumer decisions over public goods that are purchased as part of a heterogeneous marketed good tend to be based on their expectations or internal assessment of the public good. Likewise, Payne (1982) also suggests that buying decisions are dependent upon perceptual factors. As such, a consumers' subjective assessments are considered part of the modeling framework.

\section{Subjective Analysis}

David (1968) uses the hedonic technique when observing how water quality affects lakeshore properties on artificial lakes in Wisconsin. She finds that property prices were significantly correlated with a measure of water quality that represented levels of lake pollution. Water quality measurements are provided by an expert. This early work is instrumental in the creation of subjective measurements of an amenity.

Epp and Al-Ani (1979) estimate two different equations based on lake water quality and its impact on lake property values. Both the quantitative analysis (using secchi depth measurements) and the qualitative analysis (using individuals' perceptions) produce significant and positive relationships between water quality and property value. Young and Teti (1984) study the effect of perceived water quality on the vicinity of St Albans Bay on Lake Champlain in Vermont. The inclusion of water quality perceptions results in a significant and negative relationship between degraded perceived water quality and the lake homes' sales price. 
Michael, Boyle, and Brochard (2000) rate lakes for both subjective and objective water clarity. Results reveal that implicit price estimates prove significant; both the objective and subjective variables produced significant coefficients. The authors argue that the significance of the subjective variable creates concern that policy recommendations could result depending on the public perception of environmental quality and should be based on conceptually and theoretically sound logic.

Poor, et al (2001) use an objective measure of an environmental amenity (water clarity for lake front property owners) in a hedonic model and compare it to the use of a directly comparable subjective measure of the same amenity. The coefficients on both water clarity variables are significant. However, while the subjective measure is positive and significant (the greater the perceived water clarity, the higher the price), it is not as accurate as the objective variable.

The hypothesis that perception approximates reality in economic analysis is illustrated in the pricing of lake lots. In this paper on Lake Koshkonong, the difference between the real impact of the drawdown and the perceived impact cannot be separated. However, the reputation effect is the result of a real event. While real measurements of change are significant, the rumor or argument that lake levels have been reduced can have a significant and negative blow to property values.

\section{Distance From Waterfront And Shoreline Length}

A variety of locational issues impact the value of real estate. In Parsons and Wu (using 2002 dollars), the value of a home falls by $\$ 4,175$ for every mile from water. In this study, the mean sales price is $\$ 181,341$. Michael, Sides and Sullivan (2003) find that for each 100 meters of distance from shore, the property value decreases by about 3-4\% in Shady Side and Piney Point in Maryland and 18\% on the Hooper Islands. In the case of unimproved real estate, these properties witnessed a decrease in value by between $2 \%$ and $4 \%$.

One economic concern regarding the lowering of a lake's water level is its impact on quantity of shoreline. The reduction of water inside the lake ultimately results in less area covered by the lake, and thus a shorter shoreline. Given that there is an implicit value in a foot of shoreline, the elimination of shoreline eliminates wealth. The following citations are all significant at a minimum level of the 90 percent level of confidence. The consistency of these results and their significance point to a theory that, while not necessarily applicable to another lake, clearly argues that the impact of losing shoreline length is negative and significant.

Boyle and Taylor (2001) use hedonic models to estimate implicit prices on freshwater lakes and ponds in Maine. This includes the sales of properties with frontage on 34 lakes between 1990 and 1995. The lakes are segmented into four market groups whose shoreline is worth between $\$ 72$ and $\$ 456$ a foot.

The Mississippi Headwaters Board (2003) considers residential sales from 1996 to 2001 on thirty seven lakes of various size and geography. Assigning the 1205 residential sales to one of six lakes groups creates realistic market areas. This study finds that the value of a foot of lake frontage ranges from $\$ 80$ per foot to $\$ 421$ per foot.

Conner, Gibbs and Reynolds (1973) look at the value of lake or canal land frontage. The sample of vacant residential lots in Florida produces a value of $\$ 40$ per frontage foot. Poor, et al (2001) find that an additional ten feet of shoreline increases the property value by between $\$ 83$ to $\$ 170$ on lakes and ponds located in Maine.

\section{Reduction In Water Level}

In a pattern similar to the earlier research, the following papers provide insight into the general direction housing values take as the result of a drawdown. These dollar amounts are significant. The results are also consistent with the hypothesis of a negative relationship between the act of drawing down a lake's level and the property value of real estate on the lake. 
In an exhaustive study on the "Economic Effects of TVA Lake Management Policy in East Tennessee", researchers at the University of Tennessee look at the economic impact of a winter drawdown. The winter drawdown results in a decrease in the value of lake properties of $1 \%$ to $5 \%$. In addition, the benefits of delaying the winter drawdown until September $1^{\text {st }}$ range from $\$ 35$ to $\$ 4,950$ for a parcel on Douglas Lake The more valuable the property associated with the lot, the larger the effect. Drawing on a Contingent Valuation model, Hanson and Hatch (2001) determine that a permanent one foot reduction in the summer full pool water level results in a 4 to 15 percent decrease in property value.

Lansford and Jones (1995) estimate shoreline value around two Texas lakes, finding that water level at time of sale is worth about $\$ 914$ per foot of elevation. The average impact of a six foot drawdown is approximately $\$ 9,492$. Finally, Kharari-Chhrertri and Hite (1989) look at the impact of drawdowns on the sales price of vacant lots in South Carolina. They estimate that each vertical foot of drawdown reduces value by $\$ 8,454$ per acre.

\section{THE MODEL}

This paper argues that the available data indicates a change in the demand for real property on Lake Koshkonong, creating an adverse affect on property values. This adverse affect is attributed to the Indianford Dam repairs. A review of data from the South Central Wisconsin Multiple Listing Service and the Metropolitan Milwaukee Multiple Listing Service provides information regarding single family home sales from 1997 to 2005 at Lake Koshkonong. Based on the review of this data, it appears that the change in the demand for lake frontage occurs around the time of the completion of the Indianford Dam repairs.

This analysis also includes information regarding single family home sales from 1997 to 2005 at Beaver Dam Lake, a lake of similar size depth and quality, from the same sources. This information reveals that there was no similar change in demand for lake frontage at Beaver Dam Lake. This suggests that the change in demand for lake frontage that occurs at Lake Koshkonong is peculiar to Lake Koshkonong as opposed to being a universal change in the demand for lake frontage generally. It is reasonable that this sudden change in demand for Lake Frontage at Lake Koshkonong results from an event peculiar to Lake Koshkonong.

The development of the model recognizes the internal and locational attributes of lakefront real estate. Internal attributes include such characteristics as bathrooms, bedrooms, square feet, etc. The individual lake provides a key locational characteristic. Changes in the demand for any of these attributes can affect the overall demand for the given housing unit. And sometimes increases in the demand for some attributes can mask decreases in the demand for other attributes. For example, if the demand for a particular locational attribute, such as proximity to Lake Koshkonong, decrease, but the demands for all other attributes happen to increase, the sum of the increased demand outweigh the decrease in demand for the single attribute. Thus, neither a change in the demand for a particular attribute, nor the magnitude of that change, can be determined by analyzing the demand for a housing unit as a whole. However, this does not mean that the decreased demand for the single attribute, in this case proximity to Lake Koshkonong, was not real and significant. Obviously, had demand for that single attribute held steady or even increased, then the demand for the entire unit would have experienced an even greater increase.

For the purposes of determining whether a change in the character of an environmental amenity results in a change in demand for housing units for which proximity to that amenity is an attribute, it is necessary to isolate the particular characteristic of the housing unit that is most closely related to the environmental amenity. In this case the measurable characteristic of housing units around Lake Koshkonong which is most closely related to the character of the environmental amenity is shoreline frontage. In other words, changes in demand for proximity to Lake Koshkonong are indicated by changes in demand for Lake Koshkonong shoreline frontage. By isolating the demand for shoreline frontage at housing units along Lake Koshkonong, and changes thereto, from the demand for other attributes of housing units, such as demand for the interior attributes of houses around the lake indicates whether changes in the character of Lake Koshkonong have an effect on demand for housing units. 


\section{MODEL RESULTS}

Sales information comes from the South Central Wisconsin Multiple Listing Service and the Metropolitan Milwaukee Multiple Listing Service. From January 1997 to December 2006, there are 252 single family home sales on the two lakes (105 homes on Lake Koshkonong and 147 homes on Beaver Dam Lake). Water frontage was calculated from plat maps when this information was not available from the Multiple Listing Service.

As a comparison, Beaver Dam Lake was chosen because of its many similarities to Lake Koshkonong. Beaver Dam Lake covers 6,542 acres and has a maximum depth of seven feet. Similarly, Lake Koshkonong, covers 10,460 acres and also has a maximum depth of seven feet. Both are classified by DNR as "mixed drainage" lakes. The physical character of these lakes makes them similar in terms of recreational alternatives. Beaver Dam Lake is located in Dodge County. Lake Koshkonong is located on the edge of Dane, Rock and Jefferson Counties. Both lakes are geographically situated such that they are influenced by demand for Lake frontage by the Chicago, Madison and Milwaukee markets.

Lake Koshkonong's closer proximity to Chicago has made its home prices higher than those of Beaver Dam Lake. However, this paper is concerned with subsequent appreciation. One expectation is that if this location advantage dominates, Lake Koshkonong would witness higher rates of appreciation. However, it is the hypothesis of this paper that the negative impact of the DNR order negates this location advantage, resulting in greater appreciation for Beaver Dam Lake.

The hedonic equations test independent variables in an attempt to determine the appreciation of shoreline real estate on the two lakes over the past ten years. The dependent variable is the sales price of the homes, controlled for inflation. This inflation adjustment serves to translate year to year prices into more directly comparable real figures. The hedonic regressions incorporate a number of explanatory variables to capture the factors that are typically found to influence residential property prices. Of particular interest is whether the repairs to the dam and the resulting decline in water levels, cause a decrease in the appreciation of Lake Koshkonong frontage relative to Beaver Dam Lake frontage. Accordingly, we first use a binary (0-1) indicator variable denoting which lake the home was located on and a time (year) indicator variable. We create two epochs regarding the time dummies: pre-dam repair (1997-2003) and post-dam repair (2003-2006). Next, we utilize a variable denoting the linear feet of lakefront on a particular lake, and interact it with epoch indicator variables.

Finally, a variety of established housing characteristics, time and lake dummies are added to build the hedonic equation. The economic literature is replete with studies that have used housing characteristics. The coefficients used in this study are similar to those used by Brown and Pollakowski (1977) and Palmquist (1984). They include variables such as number of bedrooms, number of bathrooms, square feet of living space, the existence of an attached garage, the existence of a basement, the existence of central air conditioning, and other variables. Boyle and Taylor (2001) use shoreline feet to estimate value. This study also uses the square of shoreline feet to control for diminishing marginal benefit of shoreline. While the coefficient on shoreline feet should be positive, the coefficient of shoreline feet squared is expected to be negative, indicating a decreasing marginal benefit. The specific hedonic models estimated in this manuscript are outlined in the following section. Table 1 provides definitions and summary statistics for the variables. The model's dependent variable is the inflation adjusted sales price of a property's land and improvements (i.e., land plus dwelling).

The hedonic model includes shoreline feet interacted with epoch indicator variables as the key explanatory variables, in place of the simple binary indicator variable for shore line:

$V_{\text {it }}=\alpha+\beta_{1}\left(\right.$ Epoch $_{1} x$ LakeDummy ${ }_{1}$ Shoreline $)+\beta_{2}\left(\right.$ Epoch $_{2} x$ LakeDummy ${ }_{1} x$ Shoreline $)+$

$\beta_{3}\left(\right.$ Epoch $_{1} x$ LakeDummy $2 x$ Shoreline $)+\beta_{4}\left(\right.$ Epoch $_{2} x$ LakeDummy ${ }_{2} x$ Shoreline $)+$

$\beta_{1}\left(\right.$ Epoch $_{1} x$ LakeDummy 1 XShoreline $\left.{ }^{2}\right)+\beta_{2}\left(\right.$ Epoch $_{2}$ LLakeDummy $_{1}$ SShoreline $\left.^{2}\right)+$

$\beta_{3}\left(\right.$ Epoch $_{1} x_{\text {LakeDummy }} \mathrm{x}$ Shoreline $\left.^{2}\right)+\beta_{4}\left(\right.$ Epoch $_{2}$ LLakeDummy $_{2}$ Shoreline $\left.^{2}\right)+\delta\left(X_{\text {it }}\right)+\square_{t}\left(\right.$ Time $\left._{t}\right)+\varepsilon_{\text {it }}$ 
where Epoch $\mathrm{t}_{\mathrm{t}} \mathrm{LakeDummy}_{\mathrm{i}} \mathrm{x}$ Shoreline $\mathrm{i}_{\mathrm{i}}$ is a series of interaction terms between the time indicator variables and either the Lake Koshkonong shoreline linear feet variable or the Beaver Dam Lake shoreline linear feet variable; $\mathrm{X}_{\mathrm{it}}$ is a vector that includes the housing characteristics mentioned above; and Time $e_{t}$ represents the time indicator variables $^{1}$. The estimation of the appreciation over time of a foot of lake shoreline on Lake Koshkonong relative to a foot of lake shoreline on Beaver Dam Lake is the primary objective of the model. In other words, this attempts to determine the contribution of shoreline to the change in value of properties, ceteris paribus. Since the LM heteroskedasticity test indicates heteroskedastic variance of the error term, this paper employs a procedure proposed by White (1980) to generate heteroskedasticity-consistent estimates.

For the reasons set forth in the literature review, and assuming that the dam repairs resulted in a corresponding decline in water levels at Lake Koshkonong, one expect the results of this model to indicate that there was a slowdown in the appreciation of a foot of shoreline at Lake Koshkonong relative to Beaver Dam Lake. The results of the hedonic model verify the hypothesis. Table 2 presents the estimation of the hedonic regression results. The significance and coefficient sign of such variables as square feet, bathrooms, and air conditioning are consistent with the earlier literature. One notable variable, shoreline squared, fulfills the expectation that while shoreline has value, the marginal value of additional shoreline has diminishing value. Finally, the relative slowdown in appreciation of the value of a foot of shoreline at Lake Koshkonong, as compared to Beaver Dam Lake, is verified.

In the earliest epoch (prior to the dam repair), a foot of shoreline at Lake Koshkonong contributes $\$ 538.71$ to the value of a home $e^{2}$. During the same period, the point estimate of a foot of shoreline at Beaver Dam Lake contributes $\$ 235.45$ to the value of a home on that lake ${ }^{3}$. Following the completion of repairs to the Indianford Dam, a foot of shoreline at Lake Koshkonong contributes $\$ 961.61$ to the value of a home and a foot of shoreline on Beaver Dam Lake contributes \$447.77. In other words, the value of a foot of shoreline (in the post dam repair epoch) at Lake Koshkonong rose by $79 \%$, while the value of a foot of shoreline on Beaver Dam Lake rose by $90 \%$.

The failure of the properties at Lake Koshkonong to appreciate to the same degree as their counterparts at Beaver Dam Lake results in a significant adverse economic impact to the Lake Koshkonong region. Had the properties on Lake Koshkonong kept pace with their counterparts on Beaver Dam Lake, they would have witnessed an additional inflation adjusted appreciation of $\$ 62.90$ per foot of shoreline. Given that the average property in the Lake Koshkonong sample has lake frontage of eighty-four feet (and including the decreasing marginal benefit of additional feet of shoreline), the failure to appreciate at Lake Koshkonong translates to a loss of wealth of $\$ 13,435$ per household (or $\$ 16,521$ in current dollars) ${ }^{4}$. Of the 27 miles of shoreline, 10 miles are developed containing approximately 629 lake residences. This translates into a current aggregate loss of wealth to the community from homes that have associated lake frontage of almost $\$ 10.4$ million in 2006 dollars.

\section{CONCLUSIONS}

This research uses hedonic analysis to evaluate the effect of the completion of the repairs to the Indianford Dam and the corresponding water level decline on property values surrounding Lake Koshkonong. The analysis shows that this event resulted in financial harm to the homeowners and the community that is dependent on their wealth as a tax base. The research also confirms that the below market returns on Lake Koshkonong are attributable to this objective event and the subjective public knowledge ${ }^{5}$. As with any empirical analysis, hedonic studies are vulnerable to the omitted variable bias. It is important to reflect on the idea that, due to Beaver Dam Lake's lower prices and value, prices are converging. However, this paper builds upon the recognized theoretical link between property values and the changes in water level.

\footnotetext{
${ }^{1}$ Each year is provided a dummy variable with the 1997 time indicator variable omitted to avoid perfect multicollinearity

2 All dollar amounts are calculated in 1997 dollars based on the BLS Midwest City Class D inflation index.

${ }^{3}$ This does not include the decreasing marginal benefit of additional feet of shoreline.

${ }^{4}$ Due to a notable difference in the decreasing marginal value of shoreline on Lake Koshkonong, this change in marginal value harms property owners with greater lake frontage on Lake Koshkonong.

${ }^{5}$ We note that even with time and lake fixed effects, it is still possible that some other factors are causing the relatively higher increase in Beaver Dam Lake shoreline valuation over the later epoch. However, discussion with residents on both lakes did not reveal other possible causes.
} 
This analysis suggests that, in the absence of the dam repair and corresponding water level decline, market forces would have lead to a higher appreciation of real property values on Lake Koshkonong. By and large, the coefficients of the hedonic regression have the expected signs and magnitudes. The coefficients on the housing characteristic variables all have the anticipated sign: basement size, living space, number of bathrooms, and size of an attached garage are all positive and significant. In addition, the time indicator variables evolve from negative to positive due to the overall inflationary pressures on home values, thus indicating the general appreciation of property over time. Finally, the conclusion is robust in that it continues to hold after controlling for unmeasured, underlying factors that vary, such as unique market conditions.

As explained in the literature review, there is a theoretical link between property values and changing environmental amenities generally, and lake levels in particular. Together, the theory and empirical evidence support the hypothesis that changing lake water levels influence shoreline values on Lake Koshkonong. In this study, the repairs to the Indianford Dam, the corresponding decline in water levels at Lake Koshkonong, and the public's knowledge of these issues caused a substantial change in demand that contributed to a significant decrease in shoreline property values.

\section{REFERENCES}

1. Boyle, K.J. and L.O. Taylor. 2001. Does the Measurement of Property and Structural Characteristics Affect Estimated Implicit Prices for Environmental Amenities in a Hedonic Model? Journal of Real Estate Finance and Economics 22 (2). 303-318.

2. Brown, G., and H. Pollakowski. 1977. Economic Value of Shoreline. The Review of Economics and Statistics 59 (3). 231-249.

3. Conner, J. R., Gibbs, K. C., \& Reynolds, J. E. (1973). The Effects of water frontage on recreational property values. Journal of Leisure Research, 5 (2). 26-38.

4. David, E.L. 1968. Lakeshore Property Values: A Guide to Public Investment in Recreation. Water Resources Research 4 (4). 697-707.

5. Epp, D.J., and K. S. Al-Ani. 1979. The Effect of Water Quality on Rural Non-Farm Residential Property Values. American Journal of Agricultural Economics 61 (3). 529-534.

6. Hanson, L.U. and T.R. Hatch. 2001. Change and Conflict in Land and Water Use: Resource Valuation in conflict Resolution Among Competing Users. Journal of Agricultural and Allied Economics 33 (2). 297306.

7. Kashian, R., M. E. Eiswerth and M. Skidmore, Lake Rehabilitation and the Value of Shoreline Real Estate: Evidence from Delavan, Wisconsin, The Review of Regional Studies 2006 36(2): 221-238.

8. Khatari-Chhetri, J. B. and J. C. Hite (1989). Impact of an Interbasin Water Transfer on the Market Values of Lakeshore Properties. Working Paper, Strom Thurmond Institute, Clemson University.

9. Krystel, C., et al. 2003. Lakeshore Property Values and Water Quality. Mississippi Headwaters Board and Bemidji State University.

10. Lansford, N.H. and L.L. Jones. 1995. Marginal Price of Lake Recreation and Aesthetics: An Hedonic Approach. Journal of Agricultural and Applied Economics 27 (1). 212-223.

11. Michael, H.J., K.J. Boyle, and R. Bouchard. 2000. Does the Measurement of Environmental Quality Affect Implicit Prices Estimated from Hedonic Models? Land Economics 76 (2). 283-298.

12. Michael, J.A., D.A. Sides and T.E. Sullivan. 2003. The economic Cost of Sea Level Rise to Three Chesapeake Bay Communities. The Maryland Coastal Zone Management Program.

13. Murray, M.N., et al. 2003. Economic Effects of TVA Lake Management Policy in East Tennessee. Center for Business and Economic Research. University of Tennessee.

14. Palmquist, R.B. 1984. Estimating the Demand for the Characteristics of Housing. The Review of Economics and Statistics 66 (3). 394-404.

15. Parsons, G.R. and Y. Wu. 1991. The Opportunity Cost of Coastal and Use Controls: An Empirical Analysis. Land Economics 67 (3). 308-316.

16. Payne, J.W. 1982. Contingent Decision Behavior. Psychological Bulletin 92 (2). 382-402.

17. Poor, P.J., K.J. Boyle, L.O. Taylor, and R. Bouchard. 2001. "Objective versus Subjective Measures of Water Clarity in Hedonic Property Value Models". Land Economics 77 (4). 482-493. 
18. Puto, C.P. 1987. The Framing of Buying Decisions. Journal of Consumer Research 14 (3). $301-315$.

19. Rosen, S. 1974. Hedonic Prices and Implicit Markets: Product Differentiation in Pure Competition. Journal of Political Economy 82 (1). 34-55.

20. Singh, H. 1988. Investigating the Compatibility of Econometric Forecasts and Subjective Expectation: A Suggested Framework. Journal of Economic Psychology 9 (2). 233-249.

21. White, H. 1980. A Heteroscedasticity-Consistent Covariance Matrix Estimator and a Direct Test for Heteroscedasticity. Econometrica 48 (4). 817-838.

22. Young, C. E., and F. A. Teti. 1984. The Influence of Water Quality on the Value of Recreational Properties Adjacent to St Albans Bay. US Department of Agriculture: Economics Research Service. Natural Resource Economics Division.

Table 1: Descriptive Statistics

\begin{tabular}{|c|c|c|c|}
\hline \multicolumn{2}{|c}{ N } & Mean & Std. Deviation \\
\hline Price/Inflation & 252 & $87,029.5$ & 51.6 \\
\hline shoreline feet & 252 & 2.75 & 0.9 \\
\hline Bedrooms & 252 & 1.12 & 0.62 \\
\hline Bathrooms & 252 & 0.51 & 0.63 \\
\hline Powder Rooms & 252 & 6.47 & 7.67 \\
\hline Total Rooms & 252 & $1,467.92$ & 0.20 \\
\hline square feet & 252 & 0.46 & 0.49 \\
\hline Central Air & 252 & 0.58 & 0.49 \\
\hline if beaver 1 & 147 & 0.42 & \\
\hline if kosh 1 & 105 & & \\
\hline Year 1997 & 17 & & \\
\hline Year 1998 & 8 & & \\
\hline Year 1999 & 9 & & \\
\hline Year 2000 & 17 & & \\
\hline Year 2001 & 34 & & \\
\hline Year 2002 & 32 & & \\
\hline Year 2003 & 40 & & \\
\hline Year 2005 & 32 & & \\
\hline Year 2006 & 34 & & \\
\hline
\end{tabular}


Table 2: Hedonic Equation (1):

Value of land plus dwelling regressed on shoreline binary indicator times year interaction terms and other variables. Dependent variable is the inflation adjusted sales price of dwelling Heteroskedasticity-corrected estimates using the 252 observations

\begin{tabular}{|c|c|c|c|}
\hline Variable & Coefficient & Std. Error & t-statistic \\
\hline Const & -10332.2 & 13011.0 & -0.794 \\
\hline Bedrooms & 2424.51 & 2669.78 & 0.908 \\
\hline Bathrooms & 27521.90 & 4477.25 & $6.147 *$ \\
\hline Powder Rooms & 32412.80 & 4022.84 & $8.057 *$ \\
\hline Total Rooms & 1258.57 & 1814.88 & 0.693 \\
\hline square feet & 26.3414 & 4.6256 & $5.695 *$ \\
\hline Attached Garage & 18486.20 & 5782.15 & $3.197 *$ \\
\hline Detached Garage & 14919.80 & 5090.05 & $2.931 *$ \\
\hline Central Air & 18087.10 & 4210.43 & $4.296 *$ \\
\hline Beaver Dam Lake 1997-2002 & 235.449 & 151.169 & 1.558 \\
\hline Beaver Dam Lake 2003-2006 & 447.774 & 140.161 & $3.195^{*}$ \\
\hline Lake Koshkonong 1997-2002 & 538.711 & 180.295 & $2.988^{*}$ \\
\hline Lake Koshkonong 2003-2006 & 961.613 & 247.186 & $3.890 *$ \\
\hline $\begin{array}{c}\text { Beaver Dam Lake } \\
\text { shorelineSQ1997-2002 }\end{array}$ & -0.3910 & 0.4268 & -0.916 \\
\hline $\begin{array}{c}\text { Beaver Dam Lake } \\
\text { shorelineSQ2003-2006 }\end{array}$ & -0.5869 & 0.2476 & $-2.370 * *$ \\
\hline $\begin{array}{c}\text { Lake Koshkonong } \\
\text { shorelineSQ1997-2002 }\end{array}$ & -1.2519 & 0.6483 & $-1.931 * * *$ \\
\hline $\begin{array}{c}\text { Lake Koshkonong } \\
\text { shorelineSQ2003-2006 }\end{array}$ & -3.2276 & 1.3815 & $-2.336^{* *}$ \\
\hline
\end{tabular}

Statistics based on the weighted data:

Sum of squared residuals $=954.663$

Standard error of residuals $=2.05528$

Unadjusted $\mathrm{R}^{2}=0.926885$

Adjusted $\mathrm{R}^{2}=0.918797$

F-statistic $(25,226)=114.601(\mathrm{p}$-value $<0.00001)$

*** Significant at the $10 \%$ Level

** Significant at the 5\% Level

* Significant at the $1 \%$ Level

Date coefficients data omitted for parsimony. Data available on request. 
NOTES 